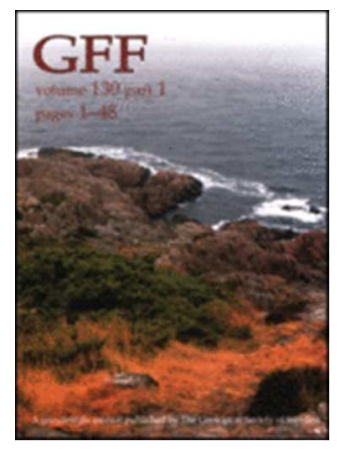

\title{
Global reef recovery after the end-Ordovician extinction: evidence from the late Aeronian coral-stromatoporoid reefs in South China
}

\begin{tabular}{|r|l|}
\hline Journal: & GFF \\
\hline Manuscript ID: & SGFF-2013-0041.R1 \\
\hline Manuscript Type: & Original Article \\
\hline Date Submitted by the Author: & $\mathrm{n} / \mathrm{a}$ \\
\hline Complete List of Authors: & $\begin{array}{l}\text { Wang, Guan; Nanjing Institute of Geology and Paleontology, Chinese } \\
\text { Academic of Sciences, } \\
\text { Li, Yue; Nanjing Institute of Geology and Palaeontology, } \\
\text { Kershaw, Stephen; Institute for the Environment, }\end{array}$ \\
\hline Keywords: & Silurian, Reefs, China, Carbonates \\
\hline
\end{tabular}

\section{SCHOLARONE \\ Manuscripts}




\title{
Global reef recovery after the end-Ordovician extinction: evidence from the late Aeronian coral- stromatoporoid reefs in South China
}

\author{
Guan Wang ${ }^{1}$ Nanjing Institute of Geology and Palaeontology, Chinese Academy of \\ Sciences, Nanjing, China, E-Mail: guanwang2010@yeah.net; \\ Yue $\mathrm{Li}^{2}$ Nanjing Institute of Geology and Palaeontology, Chinese Academy of Sciences, \\ Nanjing, China, E-Mail: yueli@nigpas.ac.cn \\ Steve Kershaw ${ }^{3}$ Institute for the Environment, Halsbury Building, Brunel University, \\ Uxbridge, UB8 3PH, UK; E-Mail: Stephen.kershaw@brunel.ac.uk \\ Deng Xiaojie $^{4}$ Guizhou Geological Survey, 550005, Guiyang, China, E-Mail: \\ tlxcc8299@qq.com
}

ABSTRACT: After the end-Ordovician mass extinction, reef recovery took several million years. On the Upper Yangtze Platform, South China Block, the initial reef reconstruction episode is recorded in limestones of the middle Aeronian Age of northern Guizhou Province. However, by the late Aeronian, reef units were widespread on the Yangtze carbonate platforms represented by patch reefs cropping out in an area about $10 \mathrm{~km}^{2}$ near Shuibatang town, Tongzi County. Two layers of reef-building are recognized: the first reef unit is generally several meters thick and tens of meters in diameter; the second patch reef unit forms well-defined mound shapes that are tens of meters thick and from tens to ca. $100 \mathrm{~m}$ laterally, with reef flanking limestones. The reefs show a complex and diverse reef community dominated by corals, and to a lesser extent stromatoporoids, as in situ frameworks; abundant bryozoan and microbial fragments occur in the reefs together with an accessory fauna of crinoids, brachiopods, trilobites and molluscs. These reefs occur during the same episode as similar reefs in Anticosti, on the Laurentian landmass, palaeogeographically very distant from South China. Thus there is good evidence that reef recovery and geographic expansion was approximately simultaneous in at least two continents, and therefore possibly global, during the late Aeronian Age in suitable shallow marine carbonate facies.

\section{INTRODUCTION}

The end-Ordovician extinction event badly affected reef environments globally (Copper, 2003), leading to a hiatus in reef development in earliest Silurian strata. The earliest small coral-stromatoporoid patch reefs appear in the Hilliste Formation, Rhuddanian, in the Baltic Basin (Nestor, 1997). Li and Kershaw (2003) demonstrated that the reconstruction of shelly biota from Rhuddanian to early Aeronian was stepwise. In contrast to the Baltic region initial recovery of coral-stromatoporoid patch reefs in South China occurred later, in the mid-Aeronian, a good example of which is in the upper Xiangshuyuan Formation in Shiqian, north Guizhou, South China Block, located palaeogeographically in the near-shoal belt of the Upper Yangtze Platform. At the time of publication of Li and Kershaw's (2003) work, evidence showed that reef radiation did not occur until the Telychian. More recently, however, Copper and Jin (2012) documented diverse reefs in the Aeronian of Anticosti, suggesting that, in at least the Laurentian region, full reef recovery was earlier than first thought. In this paper, new discoveries of Aeronian reefs in the Shinniulan Formation of northern Guizhou show that reef recovery was also earlier in China, in the late Aeronian. These new discoveries are coeval with Anticosti. Laurentia, Baltica and South China were all situated within the low latitudes of the southern hemisphere in the Early Silurian time (Golonka, 2003).

A wide northward-sloping epicontinental ramp covered northern Guizhou Province, in the Upper Yangtze Platform, during the Llandovery with terrigenous debris-dominated facies (Rong et al., 2003). Rapid expansion of carbonate facies during the late Aeronian was favourable for reef development and development of biotic diversity (Li and Kershaw, 2003). The diverse and complex reef system in the Shihniulan Member, Shihniulan Formation, late Aeronian, near Shuibatang Town, Tongzi County, has not been 
previously described. Here we document key features of its morphology and biota, and discuss the implications of their complexity for global reef recovery after the endOrdovician event.

\section{REEF-BUILDING PHASES AND BIOTIC COMPONENTS}

The Silurian sequences in northern Guizhou are uniformly subdivided, in ascending order, into the Lungmachi, Shihniulan, and Hanchiatien formations. The Lungmachi Formation (Rhuddanian-Middle Aeronian) is dark grey graptolitic shales, overlain by about $80 \mathrm{~m}$ thick of deep shelf nodular limestones of the Songkan Member, and shallow marine shelly limestones of the Shihniulan Member of the Shihniulan Formation(Late Aeronian), and then coarse silts and sandstones of the Hanchiatien Formation (lower Telychian), in ascending order. The Silurian sequence is overlain by Lower Permian limestones. Two reef units originated in shelly limestones, in the Shihniulan Member, with total thickness of about $50 \mathrm{~m}$; they are well exposed in both south and north hillsides adjacent to Shuibatang Town.

Clearly identifiable reef core and flank deposits can be seen in outcrops dissected by modern erosion. Although some of the reef tops were eroded, the vertical and lateral variations in structure can be recognised in the field. Two reef-building phases are spectacularly exposed, covering an area of about $10 \mathrm{~km}^{2}$ (Fig. 1A). The lower reef layer is generally several meters thick and tens of meters in diameter (Fig. 1B). Patch reef cores of the second layer are obvious mound shapes and reef flanks are tens of meters thick and from tens to ca. 100 m laterally (Fig. $1 \mathrm{~A}, \mathrm{~B}$ ).

The lower patch reef cores (LPRC in Fig. $1 \mathrm{~A}, \mathrm{~B}$ ) are generally rounded shapes with 5$10 \mathrm{~m}$ thickness and tens of meters in diameter (Fig. 2 A). Reef bases are about $1.5 \mathrm{~m}$ thick, comprising bioclastic packstones rich in crinoidal fragments and to a lesser extent corals, stromatoporoids, bryozoans, gastropods, brachiopods and trilobites. There are at least ten patch reefs of the second phase (the upper patch reef core, UPRC) exposed in the Shuibatang area (partly shown in Fig. 1 A, B). Reefs are diverse in thickness and diameter, which range from about $10 \mathrm{~m}$ to more than $20 \mathrm{~m}$ and from about $50 \mathrm{~m}$ to $200 \mathrm{~m}$ respectively. Compared to the lower level reefs, the upper level reefs are notable for their occasional occurrences of larger framework-building fossils (Fig. 2C). Also, reef core and flank deposits are very easily identified: patch reef cores are poorly-bedded and rich in in situ coral-stromatoporoid dominated frameworks; on the contrary, reef flanks are thinbedded argillaceous limestones rich in small bioclastic debris (of solitary rugose corals, tabulate corals, Eospirifer brachiopods, echinoderms and gastropods). Their tops, cores as well as flanks are mostly eroded into modern karst landscapes in the south hillside (Fig. 1A), but positive reliefs of the reef cores still could be traced from the cliffs in the north hillside (Fig. 1B). Between the two levels of the reefs is about a $10 \mathrm{~m}$ thick limestone unit of thin to medium bioclastic wackestones and packstones, composed of highly broken fossils dominated by solitary rugose coral and coarse crinoidal fragments (Fig. 2 B,D). On the top of the upper patch reefs is a $5 \mathrm{~m}$ thick deposit of oncolitic and echinodermal packstones (Fig. 2E), intercalated with muddy wackestones; and upward, the top of the Shihniulan Member is about $0.5 \mathrm{~m}$ of finely laminated wackestones with desiccation cracks showing occasional exposure of the marine floor (Fig.2F), unconformably overlain by the yellow-green silty mudstone of the Hanchiatien Formation, lower Telychian.

Biotic structures of the two levels of reefs are not essentially different, and both of them are rich in frameworks of tabulate corals (comprising Favosites, Mesofavosites, Paleofavosites, Troedssonites, Quasifletcheriella, Halysites, Cladopora, Coenites, Heliolites); rugose corals (comprising Enterophyllum, Parastauria, Aphyllum, Microplasma, Stauria, Ceriaster, Tabularia, Paraceriaster, Mackenziephyllum, Dentilasma, Tryplasma, Ceriaster, Cystiphyllum, Crassilasma, Rhizophyllum); stromatoporoids (including Clathrodictyon, Labechia and Plestylostroma); also present are Solenopora and the microproblematica Girvanella, and Hedstroemia. Favositids, halysitids and heliolitids are extremely abundant in both reef cores and flanks where they are diverse as fragments. In situ preserved bryozoan framework is uncommon, bryozoans are usually preserved as fragments filling cavities of coral frameworks. 
Stromatoporoids are mostly laminar and/or domical, covering coral surfaces therefore using corals as substrates. The metazoan frameworks are unevenly distributed and favourably concentrated in reef-core facies. However, reef-associated elements, including the Hormotoma (gastropod), nautiloids, Coronocephalus, Latiproetus and Encrinoides (trilobites), brachiopods and crinoidal debris of Spirocrinus and Petalocrinus and other unidentified taxa, are more abundant in more muddy reef-flank facies and are preserved commonly as highly broken debris.

\section{EVOLUTIONARY AND PALAEOGEOGRAPHIC IMPLICATIONS}

The reefs described here are approximately coeval to global reef examples on Anticosti (Laurentian continental margin), far distant from South China (Copper and Jin, 2012) and the Kazakhstan Block (Zadoroshnaya and Nikitin, 1990; Berg et al., 1980), within the low latitudes of the southern hemisphere. Thus similar reefs composed of metazoandominated biotic structures occurred around the same time period. Coral stromatoporoid - bryozoan reefs are the typical buildups in this time interval. The evolutionary implication of these reefs demonstrates that full recovery of reef environments was complete by Aeronian time in South China as well as Anticosti with high biodiversity of shallow and warm marine. Although Anticosti and South China are widely separated, the coincidence of reef recovery leads us to suggest that ocean circulation distributed reef biota globally.

In detail, Silurian reef recovery histories might differ from block to block due to variations in sedimentary sequences, and barriers created by palaeogeographic variations. Thus, we stress that as well as the aspect of evolutionary biota, the sedimentary environment is also critical for reef development. Sequences on the Yangtze Platform from the Rhuddanian through middle Aeronian are dominated by shales and silts except a very limited near-shoal belt limestone in Shiqian, in contrast to carbonatedominated Llandovery sequences in Baltica and eastern Laurentia (Anticosti). Only the Shihniulan Member of the Shihniulan Formation (late Aeronian) was shallow marine limestone facies. Thus, shallow depth of marine environments in clear (not turbid) water is key for reef growth and distribution spatially. Sedimentary evidence indicates that reef formation is governed principally by fluctuating sea level change, so that a shallowing tract of the late Aeronian promoted radiation of the reef biota of the Shihniulan Member. The results presented here indicate that reef recovery was a global feature in the Early Silurian in suitable facies; if refuges existed for reef faunas, it may be presumed that ocean circulation distributed reef biota globally.

Reefs of the Shihniulan Formation were terminated by extreme shallowing indicated by desiccation features (mud cracks) followed by deepening to deposit clastics of the Hanchiatien Formation, in the Lower Telychian, disconformably on the reef sequences. Due to short-term regression with northward expansion of the Qianzhong Land (Deng et al., 2012), the sea floor in the Shuibatang area was exposed, ending the reef-building realm. The succeeding transgression is interpreted to have produced turbid shallow marine environments in the Hanchiatien Formation, unfavourable for growth of big reefs. Some small patch reefs, with thickness generally less than $2 \mathrm{~m}$, occur in the Hanchiatien Formation in the Daijiagou and Shixi localities, which are south and north of Shuibatang respectively, indicating decline then disappearance of reefs during transgression. Thus, transgression and clastic input is interpreted to have ended the reef phase.

Acknowledgement: This study was supported by National Natural Science Foundation of China (granted No. 41072002 and 41221001). Referees of ??? and ??? are gratefully acknowledged for the comments of the manuscript.

\section{REFERENCES}

Berg L S, Keller B M, Kovalevskii O P, Tolmacheva S G, Palets L M, Bandaletov S M, Olenicheva M A. 1980. Chu-lliiskii rudnyi polyas, Geologiya Chu-iliiskovo raiona (Chu-lli mining camp Geolgy of the Chu-lli region): Alma-Ata, Nauka. 1-503

Copper P. 2002. Silurian and Devonian reefs: 80 million years of global greenhouse between two ice ages. In: Kiessling W, Flügel E, Golonka J (eds.). Phanerozoic Reef Patterns. SEPM Special Publication, 72: 181-238 
Copper, P, Jin, J. 2012. Early Silurian (Aeronian) East Point coral patch reefs of Anticosti Island, Eastern Canada: first reef recovery from the Ordovician/Silurian Mass Extinction in Eastern Laurentia. Geosciences, 2: 64-89

Deng XiaoJie, Wang Guan, Li Yue, 2012. Sedimentary characteristics at the top of the Shihniulan Formation (late Aeronian, Silurian) and their implications for identification of the shoal line in Tongzi, Northern Guizhou. Journal of Stratigraphy, 36(4): 718-722

Golonka J, 2003. Plate tectonic maps of the Phanerozoic. In: Kiessling W, Flügel E, Golonka J (eds.). Phanerozoic Reef Patterns. SEPM Special Publication, 72: 21-75

Nestor, H. 1997. Silurian. Geology and Mineral Resources of Estonia; Raukas, A., Teedumäe, A., Eds. Estonian Academy Publishers: Tallinn, Estonia, 89-106

Li Yue, Kershaw S. 2003. Reef reconstruction after extinction event of Latest Ordovician in Yangtze Platform, South China. Facies, 48: 269-284

Rong Jiayu, Chen Xu, Su Yangzheng, Ni Yunan, Zhan Renbin, Chen Tingen, Fu Lipu, Li Rongyu, Fan Juanxuan. 2003. Silurian paleogeography of China. In: Landing E, Johnson M E (eds.). Silurian Lands and Seas - Paleogeography Outside of Laurentia. New York State Museum Bulletin, 493: 243-298

Zadoroshnaya N M, Nikitin I F. 1990. Kazakhstanskaya skladchataya oblast. In: Belenitskaya G A, Zadoroshnaya N M. Rifogennye i sulfatonosnye formatsii Fanerozoya SSSR (Phanerozoic Reefal and Sulfate bearing Formations of the USSR). Ministerstvo Geologii SSSR, Moscow, Nedra, 4152

\section{FIGURE CAPTIONS}

Fig. 1. Patch reefs of the late Aeronian Shihniulan Member, Shihniulan Formation near Shuibatang town, Tongzi County, northern Guizhou Province, South China. LPRC: the lower patch reef core; LRF: the lower patch reef flank; UPRC: the upper patch reef core; URF: the upper patch reef flank.

A: Silurian and overlying Permian sequences showing reef cores and reef flanks in the north hillside. (B) reef cores and reef flanks in the south hillside. A-F showing the reef subfacies in A and B.

Fig. 2. Details of facies of Aeronian Shihniulan Member. A: coral-stromatoporoid frameworks of the LPRC. B: reef-base of the UPRC. C: UPRC reef components of corals and stromatoporoids. D: UPRC reef-base rich in bioclasts. E: the top of the UPRC covered by oncolitic packstones. F: the desiccation cracks at the top of the Shihniulan Member showing regressional tract exposed above the sea-floor. 


\section{Page 5 of 12}

GFF

Fig. 1

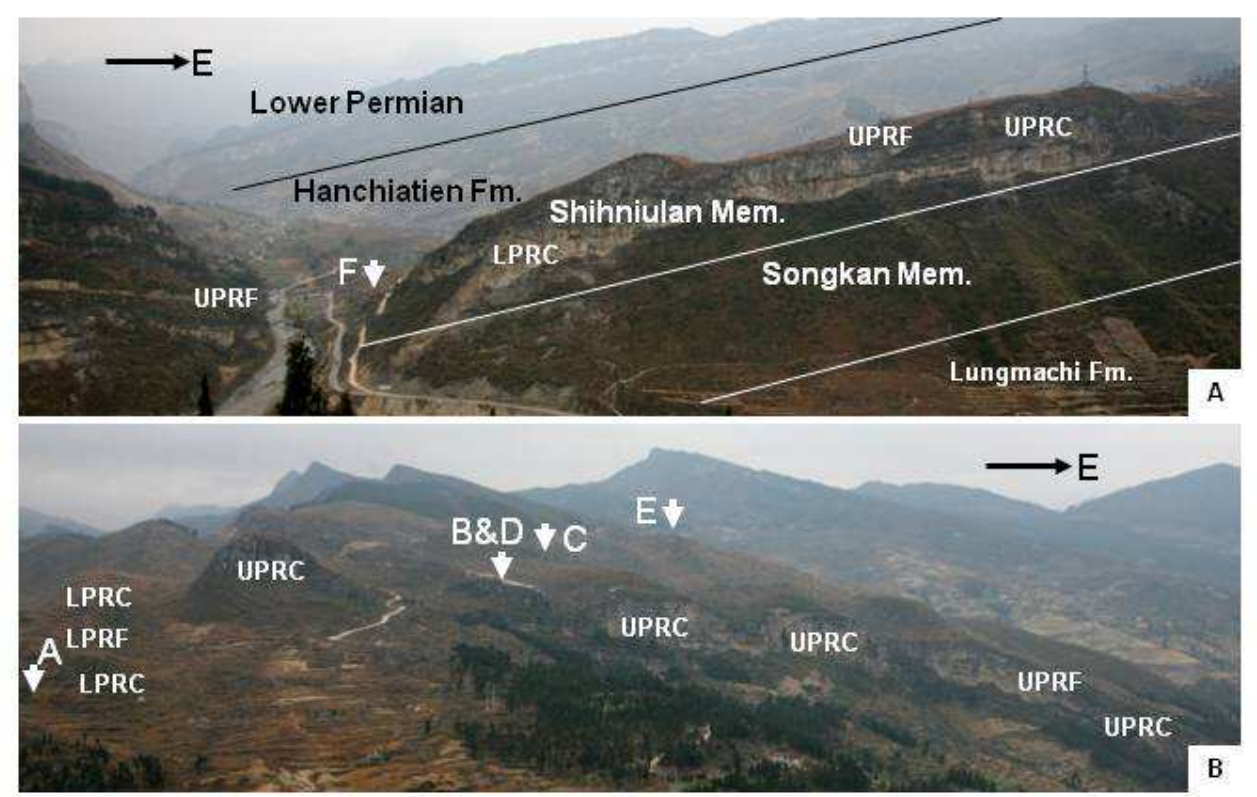

3

4

5

6
7

8

9

10

11

12 
Fig. 2

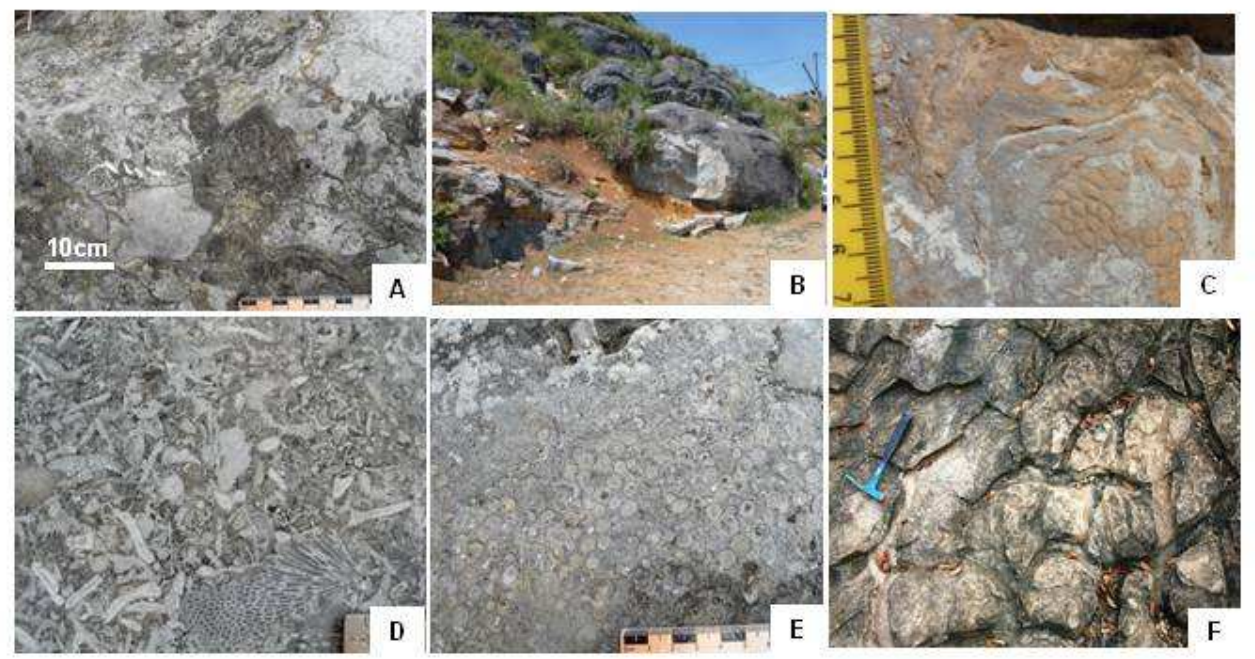

URL: http://mc.manuscriptcentral.com/sgff Email: Mikael.Calner@geol.Iu.se 
Guan Wang ${ }^{1}$ Nanjing Institute of Geology and Palaeontology, Chinese Academy of Sciences, Nanjing, China, E-Mail: guanwang2010@yeah.net;

Yue $\mathrm{Li}^{2}$ Nanjing Institute of Geology and Palaeontology, Chinese Academy of Sciences, Nanjing, China, E-Mail: yueli@nigpas.ac.cn

Steve Kershaw ${ }^{3}$ Institute for the Environment, Halsbury Building, Brunel University, Uxbridge, UB8 3PH, UK; E-Mail: Stephen.kershaw@brunel.ac.uk

Deng Xiaojie $^{4}$ Guizhou Geological Survey, 550005, Guiyang, China, E-Mail: t1xcc8299@qq.com

ABSTRACT: After the end-Ordovician mass extinction, reef recovery (size and biotic diversity) took several million years. On the Upper Yangtze Platform, South China Block, the initial reef reconstruction episode is recorded in limestones of the middle Aeronian age of northern Guizhou Province. However, by the late Aeronian, reef units were widespread on the Yangtze carbonate platforms represented by patch reefs cropping out in an area about $10 \mathrm{~km}^{2}$ near Shuibatang town, Tongzi County. Two layers of reefbuilding are recognized: the first reef unit is generally several metres thick and tens of metres in diameter; the second patch reef unit forms well-defined mound shapes that are tens of metres thick and from tens to ca. $100 \mathrm{~m}$ laterally, with reef flanking limestones. The reefs show a complex and diverse reef community dominated by corals, and to a lesser extent stromatoporoids, as in situ frameworks. The reefs contain an accessory fauna consisting of abundant bryozoan and crinoids fragments and some brachiopods, trilobites, molluscs and calcimicrobes. These reefs occur during the same episode as similar reefs in Anticosti, on the Laurentian landmass, palaeogeographically very distant from South China. Thus there is good evidence that reef recovery and geographic expansion was approximately simultaneous in at least two continents, and therefore possibly global, during the late Aeronian time in suitable shallow-marine carbonate facies.

\section{INTRODUCTION}

The end-Ordovician extinction event adversely affected reef environments globally (Copper, 2003), leading to a hiatus in reef development in earliest Silurian strata. The earliest small coral-stromatoporoid patch reefs appear in the Hilliste Formation, Rhuddanian, in the Baltic Basin (Nestor, 1997). Li and Kershaw (2003) demonstrated that the reconstruction of shelly biota from Rhuddanian to early Aeronian was stepwise. In contrast to the Baltic region initial recovery of coral-stromatoporoid patch reefs in South China occurred later, in the mid-Aeronian, a good example of which is in the upper Xiangshuyuan Formation in Shiqian, north Guizhou, South China Block, located palaeogeographically in the near-shoal belt of the Upper Yangtze Platform. At the time of publication of Li and Kershaw's (2003) work, evidence showed that reef radiation did not occur until the Telychian. More recently, however, Copper and Jin (2012) documented diverse reefs in the Aeronian of Anticosti, suggesting that, in at least the Laurentian region, full reef recovery was earlier than first thought. In this paper, new discoveries of Aeronian reefs in the Shihniulan Formation of northern Guizhou show that full reef recovery was also earlier in China, in the late Aeronian. These new discoveries are coeval with Anticosti. Laurentia, Baltica and South China were all situated within the low latitudes of the southern hemisphere in the Early Silurian time (Golonka, 2003).

A wide northward-sloping epicontinental ramp covered northern Guizhou Province, in the Upper Yangtze Platform, during the Llandovery with terrigenous debris-dominated facies (Rong et al., 2003). Rapid expansion of carbonate facies during the late Aeronian was favourable for reef development and development of biotic diversity ( $\mathrm{Li}$ and Kershaw, 2003). The diverse and complex reef system in the Shihniulan Member, Shihniulan Formation, is known to be late Aeronian age (Rong et al., 2003, Fig. 2) and is located 
near Shuibatang Town, Tongzi County. The reef complex has not been previously described. Here we document key features of its morphology and biota using a combination of field and thin section descriptions, and discuss the implications for global reef recovery after the end-Ordovician event.

\section{REEF-BUILDING PHASES AND BIOTIC COMPONENTS}

The Silurian sequences in northern Guizhou are uniformly subdivided, in ascending order, into the Lungmachi, Shihniulan, and Hanchiatien formations. The Lungmachi Formation (Rhuddanian-Middle Aeronian) is dark grey graptolitic shales, overlain by about $80 \mathrm{~m}$ thick of deep shelf nodular limestones of the Songkan Member, and shallow-marine shelly limestones of the Shihniulan Member of the Shihniulan Formation (Late Aeronian), and then coarse silts and sandstones of the Hanchiatien Formation (lower Telychian), in ascending order. The Silurian sequence is overlain by Lower Permian limestones. Two reef units originated in shelly limestones, in the Shihniulan Member, with total thickness of about $50 \mathrm{~m}$; they are well exposed in both south and north hillsides adjacent to Shuibatang Town.

Clearly identifiable reef core and flank deposits can be seen in outcrops dissected by modern erosion. Although some of the reef tops were eroded, the vertical and lateral variations in structure can be recognised in the field. Two reef-building phases are spectacularly exposed, with the reef phases each covering an area of about $10 \mathrm{~km}^{2}$ overall (Fig. 1A). The lower reef layer is generally several metres thick and contains reefs that are tens of metres in diameter (Fig. 1B). Patch reef cores of the second layer are obvious mound shapes and reef flanks are tens of metres thick and from tens to ca. 100 m laterally (Fig. 1, A, B).

The lower patch reef cores (LPRC in Fig. $1 \mathrm{~A}, \mathrm{~B})$ are generally rounded shapes with 5$10 \mathrm{~m}$ thickness and tens of metres in diameter (Fig. 1C). Reef bases are about $1.5 \mathrm{~m}$ thick, comprising bioclastic packstones rich in crinoidal fragments and to a lesser extent corals, stromatoporoids, bryozoans, gastropods, brachiopods and trilobites. There are at least ten patch reefs of the second phase (the upper patch reef core, UPRC) exposed in the Shuibatang area (partly shown in Fig. 1, A, B). Reefs are diverse in thickness and diameter, which range from about $10 \mathrm{~m}$ to more than $20 \mathrm{~m}$ and from about $50 \mathrm{~m}$ to $200 \mathrm{~m}$ respectively. Compared to the lower level reefs, the upper level reefs are notable for their occasional occurrences of larger framework-building fossils (Fig. 1E). Also, reef core and flank deposits are very easily identified: patch reef cores are poorly-bedded and rich in in situ coral-stromatoporoid dominated frameworks. The reefs contain an accessory fauna consisting of abundant bryozoan and crinoids fragments and some brachiopods, trilobites, molluscs and calcimicrobes. On the contrary, reef flanks are thin-bedded argillaceous limestones rich in small bioclastic debris (of solitary rugose corals, tabulate corals, Eospirifer brachiopods, echinoderms and gastropods Fig. 1F). Reef tops, cores as well as flanks are mostly eroded to form modern karst landscapes in the south hillside (Fig. $1 \mathrm{~A}$ ), but positive reliefs of the reef cores still could be traced from the cliffs in the north hillside (Fig. 1B). Between the two levels of the reefs is about a $10 \mathrm{~m}$ thick limestone unit of thin to medium bioclastic wackestones and packstones, composed of highly broken fossils dominated by solitary rugose coral and coarse crinoidal fragments (Fig. 1D). On the top of the upper patch reefs is a $5 \mathrm{~m}$ thick deposit of oncolitic and echinodermal packstones (Fig. 1G), intercalated with muddy wackestones; and upward, the top of the Shihniulan Member is about $0.5 \mathrm{~m}$ of finely laminated wackestones with desiccation cracks showing occasional exposure of the marine floor $($ Fig. $1 \mathrm{H})$, unconformably overlain by the yellow-green silty mudstone of the Hanchiatien Formation, lower Telychian.

The communities of the two reef phases are not essentially different, and both of them are rich in frameworks of tabulate corals (comprising Favosites, Mesofavosites, Paleofavosites, Troedssonites, Quasifletcheriella, Halysites, Cladopora, Coenites, Heliolites); rugose corals (comprising Enterophyllum, Parastauria, Aphyllum, Microplasma, Stauria, Ceriaster, Tabularia, Paraceriaster, Mackenziephyllum, Dentilasma, Tryplasma, Ceriaster, Cystiphyllum, Crassilasma, Rhizophyllum); stromatoporoids (including Clathrodictyon, Labechia and Plestylostroma); also present are Solenopora and the microproblematica Girvanella, and Hedstroemia. Favositids, 
halysitids and heliolitids are extremely abundant in both reef cores and flanks where they are diverse as fragments. In situ preserved bryozoan framework is uncommon, bryozoans are usually preserved as fragments filling cavities of coral frameworks. Stromatoporoids are mostly laminar and/or domical, covering coral surfaces therefore using corals as substrates. The metazoan frameworks are unevenly distributed and favourably concentrated in reef-core facies. However, reef-associated elements, including the Hormotoma (gastropod), nautiloids, Coronocephalus, Latiproetus and Encrinoides (trilobites), brachiopods and crinoidal debris of Spirocrinus and Petalocrinus and other unidentified taxa, are more abundant in more muddy reef-flank facies and are preserved commonly as highly broken debris.

\section{EVOLUTIONARY AND PALAEOGEOGRAPHIC IMPLICATIONS}

The reefs described here are approximately coeval to Anticosti (Laurentian continental margin), far distant from South China (Copper and Jin, 2012) and the Kazakhstan Block (Zadoroshnaya and Nikitin, 1990; Berg et al., 1980), within the low latitudes of the southern hemisphere. Thus similar reefs composed of metazoan-dominated biotic structures occurred around the same time period. Coral - stromatoporoid - bryozoan reefs are the typical buildups in this time interval. Thus we demonstrate that full recovery of reef environments was complete by Aeronian time in South China as well as Anticosti with high biodiversity of shallow and warm marine environments. Although Anticosti and South China are widely separated, the coincidence of reef recovery leads us to suggest that ocean circulation distributed reef biota globally.

In detail, Silurian reef recovery histories might differ from block to block due to variations in environmental factors, and barriers created by palaeogeographic variations. Thus, we stress that as well as the aspect of evolutionary biota, the sedimentary environment is also critical for reef development. Sequences on the Yangtze Platform from the Rhuddanian through middle Aeronian are dominated by shales and silts except a very limited near-shoal belt limestone in Shiqian, in contrast to carbonate-dominated Llandovery sequences in Baltica and eastern Laurentia (Anticosti). Only the Shihniulan Member of the Shihniulan Formation (late Aeronian) was shallow-marine limestone facies. Thus, shallow depth of marine environments in clear (not turbid) water is key for reef growth and distribution spatially. Sedimentary evidence indicates that reef formation is governed principally by sea level change, so that shallowing during the late Aeronian promoted radiation of the reef biota of the Shihniulan Member. The results presented here indicate that reef recovery was a global feature in the Early Silurian in suitable facies; if refuges existed for reef faunas, it may be presumed that ocean circulation distributed reef biota globally.

Reefs of the Shihniulan Formation were terminated by shallowing indicated by oncolites overlain by desiccation features (mud cracks). This created a short-term regression with northward expansion of the Qianzhong Land (Deng et al., 2012) leading to exposure of the sea floor in the Shuibatang area, ending the reef-building realm. The disconformity on the reef tops was covered by clastics of the Lower Telychian Hanchiatien Formation, representing deepening of water in a transgression interpreted to have produced turbid shallow-marine environments unfavourable for growth of big reefs. Some small patch reefs, with thickness generally less than $2 \mathrm{~m}$, occur in the Hanchiatien Formation in the Daijiagou and Shixi localities, which are south and north of Shuibatang respectively, indicating decline then disappearance of reefs during transgression. Thus, transgression and clastic input are interpreted to have ended the reef phase.

Acknowledgement: This study was supported by National Natural Science Foundation of China (granted No. 41072002 and 41221001). Comments by Maurice Tucker and Wolfgang Kiessling have improved the manuscript.

\section{REFERENCES}

Berg L S, Keller B M, Kovalevskii O P, Tolmacheva S G, Palets L M, Bandaletov S M, Olenicheva M A. 1980. Chu-lliiskii rudnyi polyas, Geologiya Chu-iliiskovo raiona (Chu-Ili mining camp Geolgy of the Chu-Ili region): Alma-Ata, Nauka. 1-503 
Copper P. 2002. Silurian and Devonian reefs: 80 million years of global greenhouse between two ice ages. In: Kiessling W, Flügel E, Golonka J (eds.). Phanerozoic Reef Patterns. SEPM Special Publication, 72: 181-238

Copper, P, Jin, J. 2012. Early Silurian (Aeronian) East Point coral patch reefs of Anticosti Island, Eastern Canada: first reef recovery from the Ordovician/Silurian Mass Extinction in Eastern Laurentia. Geosciences, 2: 64-89

Deng XiaoJie, Wang Guan, Li Yue, 2012. Sedimentary characteristics at the top of the Shihniulan Formation (late Aeronian, Silurian) and their implications for identification of the shoal line in Tongzi, Northern Guizhou. Journal of Stratigraphy, 36(4): 718-722

Golonka J, 2003. Plate tectonic maps of the Phanerozoic. In: Kiessling W, Flügel E, Golonka J (eds.). Phanerozoic Reef Patterns. SEPM Special Publication, 72: 21-75

Nestor, H. 1997. Silurian. Geology and Mineral Resources of Estonia; Raukas, A., Teedumäe, A., Eds. Estonian Academy Publishers: Tallinn, Estonia, 89-106

Li Yue, Kershaw S. 2003. Reef reconstruction after extinction event of Latest Ordovician in Yangtze Platform, South China. Facies, 48: 269-284

Rong Jiayu, Chen Xu, Su Yangzheng, Ni Yunan, Zhan Renbin, Chen Tingen, Fu Lipu, Li Rongyu, Fan Juanxuan. 2003. Silurian paleogeography of China. In: Landing E, Johnson M E (eds.). Silurian Lands and Seas - Paleogeography Outside of Laurentia. New York State Museum Bulletin, 493: 243-298

Zadoroshnaya N M, Nikitin I F. 1990. Kazakhstanskaya skladchataya oblast. In: Belenitskaya G A, Zadoroshnaya N M. Rifogennye i sulfatonosnye formatsii Fanerozoya SSSR (Phanerozoic Reefal and Sulfate bearing Formations of the USSR). Ministerstvo Geologii SSSR, Moscow, Nedra, 4152

\section{FIGURE CAPTIONS}

Fig. 1. Patch reefs of the late Aeronian Shihniulan Member, Shihniulan Formation near Shuibatang town, Tongzi County, northern Guizhou Province, South China. LPRC: the lower patch reef core; LRF: the lower patch reef flank; UPRC: the upper patch reef core; URF: the upper patch reef flank. A: Silurian and overlying Permian sequences showing reef cores and reef flanks in the north hillside. (B) reef cores and reef flanks in the south hillside. A-F showing the reef subfacies in A and B.

Fig. 2. Details of facies of Aeronian Shihniulan Member. A: coral-stromatoporoid frameworks of the LPRC. B: reef-base of the UPRC. C: UPRC reef components of corals and stromatoporoids. D: UPRC reef-base rich in bioclasts. E: the top of the UPRC covered by oncolitic packstones. F: the desiccation cracks at the top of the Shihniulan Member showing regressional tract exposed above the sea-floor. 
Fig. 1

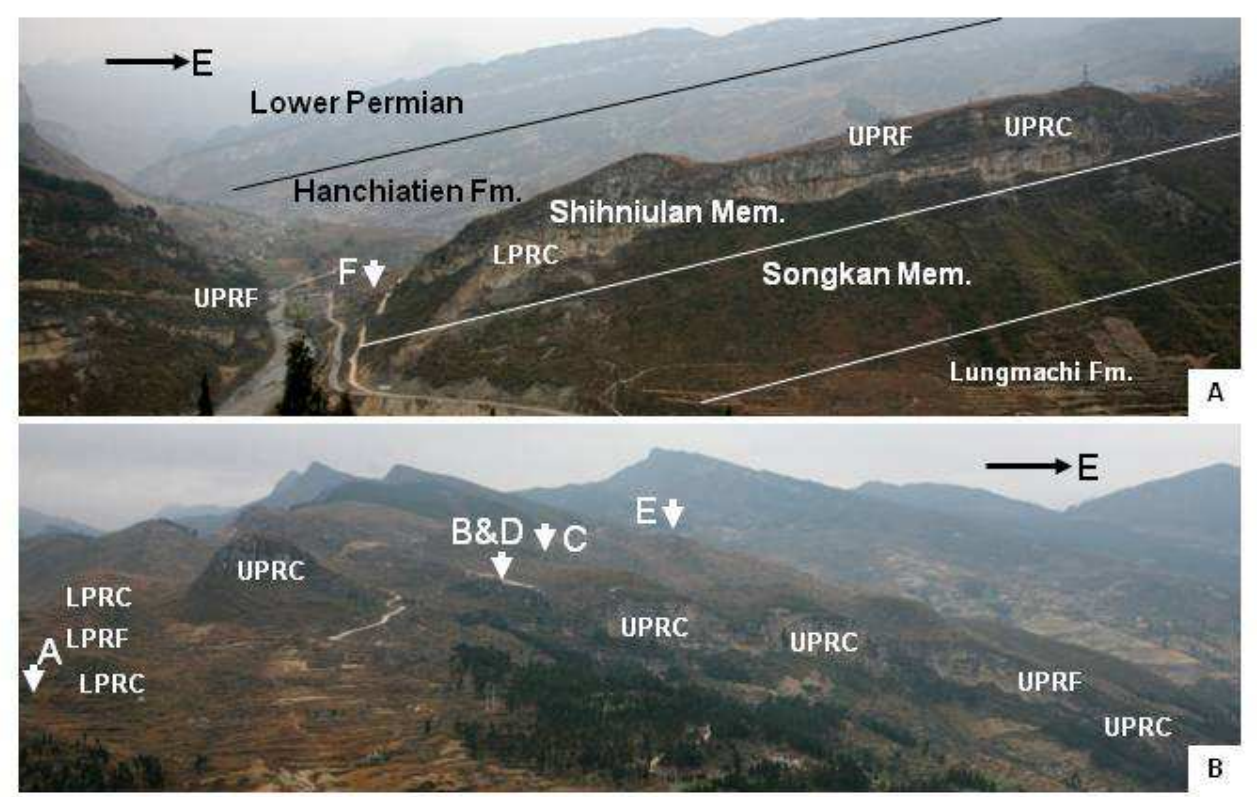

3

4

5

6
7

8

9

10 
Fig. 2

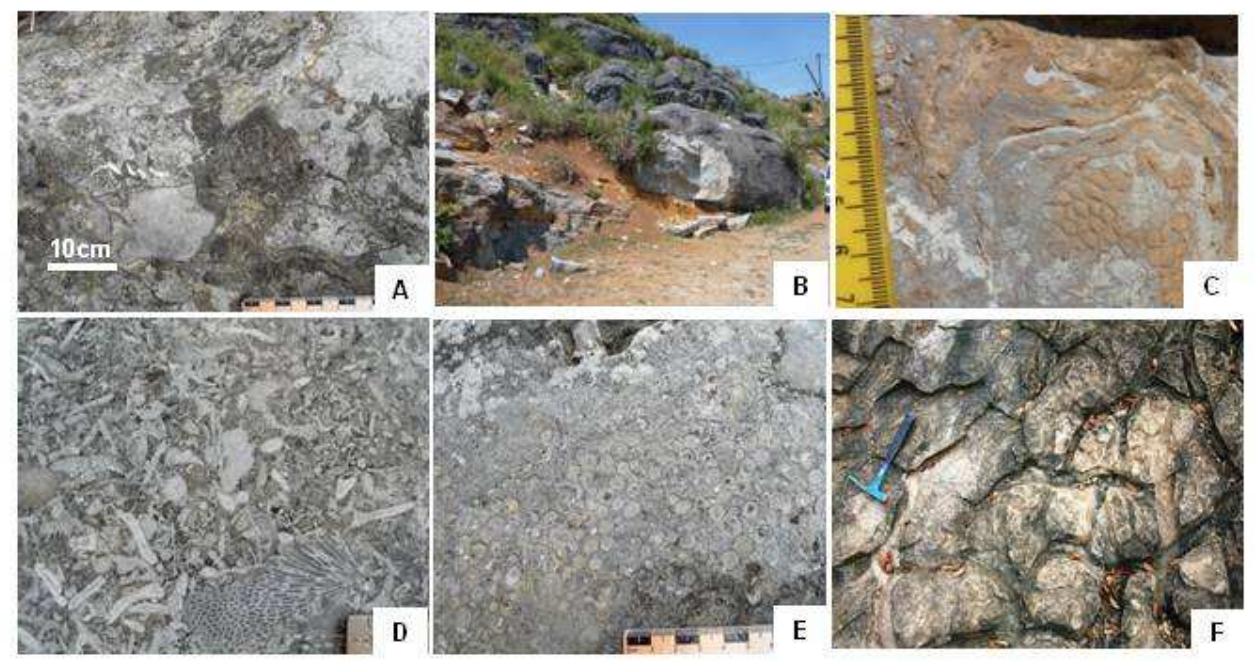

URL: http://mc.manuscriptcentral.com/sgff Email: Mikael.Calner@geol.Iu.se 